\title{
Implementasi Data Mining Dalam Data Bencana Tanah Longsor Di Jawa Barat Menggunakan Algoritma $F p$ - Growth
}

\author{
Data Mining Implementation For Landslide Data In West Java Using Fp-Growth \\ Algorithm
}

\author{
Castaka Agus Sugianto ${ }^{1}$, Melani Nur Astita ${ }^{2}$ \\ Program Studi Teknik Informatika - Politeknik TEDC Bandung \\ Jl. Politeknik-Pesantren KM2 Cibabat Cimahi Utara - Cimahi - Jawa Barat - Indonesia \\ e-mail: ${ }^{1}$ castaka@poltektedc.ac.id, ${ }^{2}$ melani.astita@ gmail.com
}

\begin{abstract}
Abstrak
Jawa Barat merupakan salah satu zona rawan longsor di Indonesia. Pengurangan resiko bencana diantaranya adalah peringatan dini dengan langkah awal menganalisis data yang ada. Salah satu cara menganalisis data ini yaitu dengan teknik data mining. Tujuan penelitian ini adalah untuk mengetahui pola hubungan aturan assosiatif antara suatu kombinasi data dan membentuk pola kombinasi datasets dengan menggunakan algoritma Fp-growth dalam data bencana tanah longsor yang di dapat dari Badan Nasional Penanggulangan Bencana dan Badan Penanggulangan Bencana Daerah Provinsi Jawa Barat periode data dari 2011 sampai dengan 2016. Hasil penelitian ini mendapatkan nilai confidence tertinggi sebesar 1 dengan premises malam, jalan rusak dan conclusion hujan deras dan premises tanah labil, korban jiwa, sore dengan conclusion hujan deras yang berarti keterkaitan satu kondisi dengan kondisi lain sebesar $100 \%$. Untuk nilai support tertinggi dalam pola asosiatif didapatkan sebesar 0,629 dengan confidence 0,901 dengan premises rumah rusak dan conclusion hujan deras yang berarti $90 \%$ keterkaitan dengan kejadian $63 \%$ kemunculan.
\end{abstract}

Kata kunci-longsor, jawa barat, data mining, asosiasi, fp-growth

\begin{abstract}
West Java is one of the landslide precarious zone in Indonesia. Disaster risk reduction include early warning with initial steps to analyze existing data. One of the way to analyze data is by data mining techniques. The purpose of this research is to know the pattern of associative relationship between a combination of data and form a combination of datasets pattern using FP-Growth algorithm in landslide data from National Disaster Management Institution and West Java Province Disaster Management Institution from data period 2011 to 2016. The results of this research get the highest confidence value of 1 with premises malam, jalan rusak and conclusion hujan deras and 2 nd premises tanah labil, korban jiwa, sore with conclusion hujan deras which means the relationship of one condition with another condition of 100\%. For the highest support value in the associative pattern is 0.629 with confidence of 0.901 the premise is jalan rusak and hujan deras as conclusion, which means $90 \%$ correlation with $63 \%$ occurrence.
\end{abstract}

Keywords-landslide, west java, data mining, association rules, fp-growth 


\section{PENDAHULUAN}

Tanah longsor adalah suatu jenis gerakan tanah yang terjadi saat lapisan bumi paling atas dan bebatuan terlepas dari bagian utama gunung atau bukit [1]. Hal ini biasanya terjadi karena curah hujan yang tinggi. Kasus ini terutama pada iklim lembab dan panas seperti di Indonesia. Tanah longsor adalah suatu peristiwa alam yang pada saat ini frekuensi kejadiannya semakin meningkat. Jawa Barat sendiri merupakan daerah paling rawan longsor di Indonesia. Pasalnya, Jawa Barat merupakan zona merah karena memiliki kondisi geografis yang hampir setengahnya berbukit dan berlembah. Sehingga memiliki kerentanan tanah tinggi alias rawan longsor. Dari mulai wilayah utara hingga selatan Jawa Barat berpotensi longsor dengan ciri-ciri selain perbukitan dan lembah, juga tanahnya subur, dan memiliki banyak mata air [2].

Hampir sebagian wilayah Jawa Barat termasuk kategori rawan longsor, terutama di saat musim hujan. Ada 13 kota dan kabupaten di Jawa Barat yang tanahnya mudah longsor, antara lain Cirebon bagian selatan, Kuningan, Sumedang, Bandung, Subang, Bandung Barat, Ciamis, Tasikmalaya, Garut, Bogor dan Sukabumi [2]. Fenomena alam ini berubah menjadi bencana alam manakala tanah longsor tersebut menimbulkan korban baik berupa korban jiwa maupun kerugian harta benda dan hasil budaya manusia. Indonesia yang sebagian wilayahnya berupa daerah perbukitan dan pegunungan, menyebabkan sebagian wilayah Indonesia menjadi daerah yang rawan kejadian bencana tanah longsor. Intensitas curah hujan yang tinggi dengan keadaan wilayah dan tanah yang tidak benar dapat memicu terjadinya bencana alam tanah longsor. Dalam kejadian bencana tanah longsor di Jawa Barat sepanjang 2016 sampai November, tercatat 76 orang meninggal dunia, 28 orang korban luka, dan lebih dari 1.000 rumah rusak. [3]. Kerugian dan kerusakan ini cukup besar dibandingkan dengan sumbangan ekonomi akibat pemanfaatan ruang dan lahan di daerah-daerah rawan bencana tersebut. Besarnya kerugian dan kerusakan ekonomi akibat bencana tersebut disebabkan masih minimnya upaya-upaya pengurangan risiko bencana yang dapat meminimumkan dampak bencana. Pengurangan resiko bencana diantaranya adalah peringatan dini. Bencana alam merupakan suatu kejadian yang tidak bisa dihindari. Namun dampak bencana dapat dikurangi atau dapat diminimalisir dengan mengenali penyebab bencana dan mempelajari kejadian bencana yang telah terjadi dengan menganalisis data bencana-bencana yang ada sehingga menghasilkan satu sistem peringatan dini.

Salah satu cara menganalisis data ini yaitu dengan teknik data mining. Seperti penelitian lain yang juga meneliti data bencana tanah longsor yang dilakukan oleh Dewi Setianingsih dan RB Fajriya Hakim [4] yaitu penerapan data mining dalam analisis kejadian tanah longsor di Indonesia dengan menggunakan association rules algoritma apriori. Dengan hasil pola hubungan assosiatif yang terjadi dari data tanah longsor di Indonesia pada akhir bulan desember 2014 dan awal bulan januari 2015 dengan nilai support tertinggi didapat hasil, jika terjadi tanah longsor dengan kondisi tanah labil maka hujan deras dengan nilai support sebesar 0.5227273 dan nilai confidence sebesar 0.8214286 dan jika terjadi tanah longsor karena hujan deras maka kondisi tanah labil dengan nilai support sebesar 0.5227273 dan nilai confidence sebesar 0.6969697. Penelitian yang dilakukan oleh Muhamad Iqbal Ramadhan dan Prihandoko [5] mengenai penerapan data mining untuk analisis data bencana milik bnpb menggunakan algoritma $k$-means dan linear regression. Data yang digunakan pada penelitian ini adalah datadari BNPB yang merupakan data bencana alam dari 34 provinsi yang ada di Indonesia dari tahun 2015 - 2015. Dari penelitian ini menunjukan hasil cluster bahwa Provinsi Jawa Tengah memiliki jumlah bencana tanah longsor terbesar. Berikutnya berdasarkan hasil prediksi periode tahun 2016-2020 menujukan bahwa Provinsi Jawa Barat memiliki jumlah bencana tanah longsor terbesar. Kemudian berdasarkan hasil prediksi menunjukan bencana banjir akan tetap menjadi bencana yang mendominasi di 20 provinsi yang ada di Indonesia. Penelitian yang dilakukan oleh Muhammad Faishal Afif [6] dengan judul penerapan algoritma self organizing map dalam memetakan daerah rawan bencana tanah longsor di Indonesia, dapat disimpulkan bahawa proses pembelajaran algoritma Self Organizing Map menghasilkan model cluster terbaik dengan jumlah 33 neuron input dan 9 neuron output. Algoritma Self Organizing Map menghasilkan 
9 cluster yang tentunya pada masing-masing cluster memiliki karakteristik yang berbedabeda. Penelitian ini memiliki Perbedanan dari 3 penelitian sebelumnya yaitu data yang digunakan fokus pada data bencana longsor yang terjadi pada Provinsi Jawa Barat dan data yang digunakan dari tahun 2011 - 2016 dan algoritma yang digunakan yaitu FP-Growth untuk mengetahui hubungan assosiatif dari data tanah longsor.

Algoritma yang sering digunakan dalam metode association rules yaitu FP-Growth, A priori, GRI. Diantara algoritma pattern-mining lainnya, algoritma FP-Growth lebih efisien dan terukur [7]. Algoritma FP-Growth dapat menghemat waktu dan ruang penyimpanan dan penggunaan sarana partisi sehingga dapat menghindari database sekala besar. FP-Growth dianggap lebih efisien karena tidak perlu menghasilkan generate candidate item. FP-Growth kerjanya dengan membaca kumpulan data dari satu transaksi tertentu kemudian memetakan kedalam bagian Frequent Pattren Tree[8]. Dengan menerapkan teknik data mining metode association rules dalam bencana tanah longsor di Jawa Barat diharapkan akan menghasilkan pengetahuan yang dapat membantu memberi solusi permasalahan yang muncul.

\section{METODE PENELITIAN}

Ada 9 (sembilan) tahapan yang akan dilakukan penulis. Diantaranya:

\subsection{Penentuan Masalah}

Penentuan masalah adalah langkah pertama yang dilakukan dalam penelitian ini. Penentuan masalah sudah dilakukan dengan observasi di kantor Badan Penanggulangan Bencana Daerah Provinsi Jawa Barat yang dilakukan pada 5 Januari 2017 sampai dengan 20 Januari 2017, Observasi dilakukan dengan mengamati kegiatan di kantor Badan Penanggulangan Bencana Daerah Provinsi Jawa Barat, serta mempelajari data yang didapat, dan juga beberapa indikator penyebab terjadinya bencana tanah longsor di beberapa daerah di Jawa Barat, kemudian menentukan masalah seperti yang telah yang telah dijelaskan pada bab 1 dengan diperkuat oleh statistika kejadian tanah longsor di Indonesia dari periode tahun 2000 sampai 2016 yang didapatkan dari website Badan Nasional Penanggulangan Bencana seperti pada Gambar 1 dibawah ini.

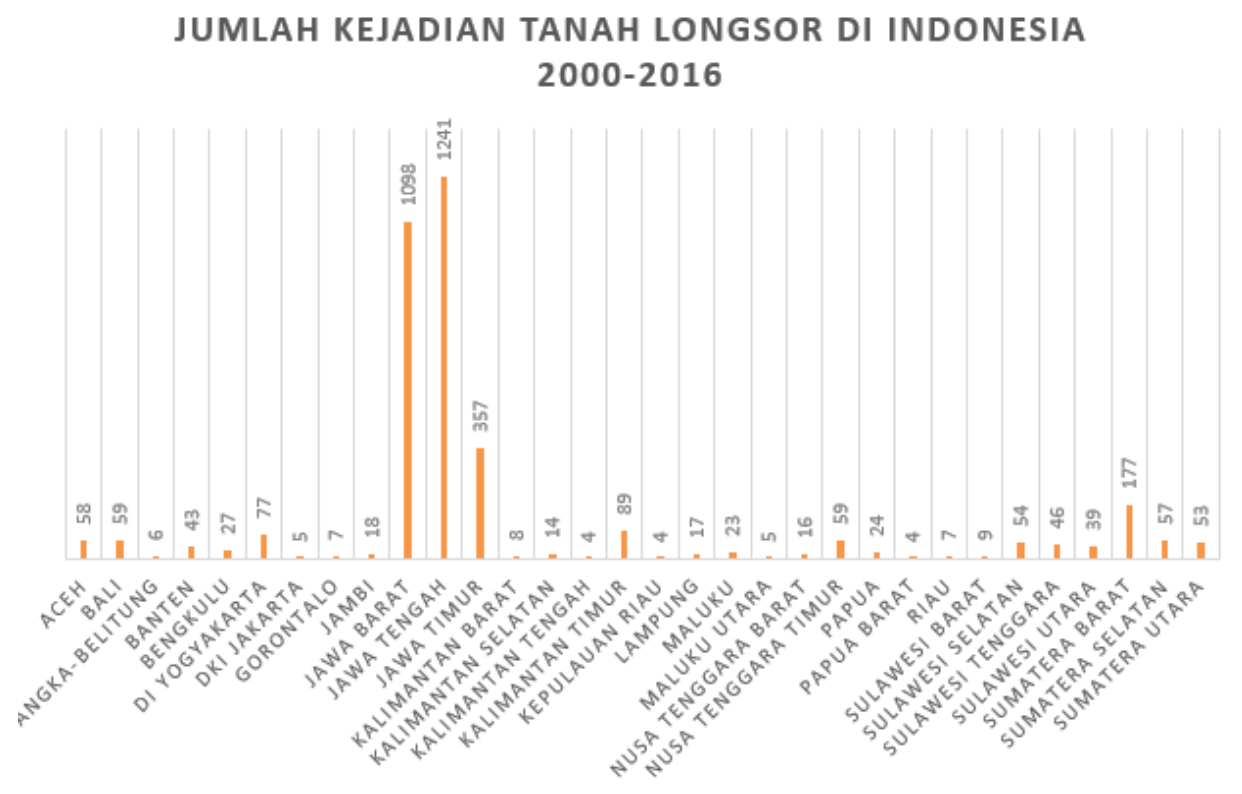

Gambar 1. Statistik Bencana Longsor di Indonesia Tahun 2000-2016

Dari data statistik dapat dilihat bahwa daerah yang paling sering mengalami tanah longsor adalah Jawa Tengah dan Jawa Barat menduduki peringkat kedua. Dikarenakan keterbatasan 
waktu pengerjaan dan mengingat penulis berdomisili di Jawa Barat yang juga merasakan langsung dampak bencana tanah longsor yang terjadi di Jawa Barat maka Jawa Barat dipilih menjadi tempat studi kasus ini diambil.

\subsection{Menentukan Tujuan dan Ruang Lingkup}

Penentuan tujuan dan ruang lingkup merupakan apa yang ingin di capai oleh penulis dalam penelitian serta batasan yang di pakai agar penelitian tidak terlalu melebar. Ruang lingkup penelitiannya yaitu analisis kejadian tanah longsor pada periode 2011 sampai 2016 yang terjadi di provinsi Jawa Barat berdasarkan data yang didapatkan dari website resmi Badan Nasional Penganggulangan Bencana dan kantor Badan Penanggulangan Bencana Daerah Provinsi Jawa Barat. Tujuan yang ingin dicapai yaitu untuk mengetahui pola hubungan aturan assosiatif antara suatu kombinasi data dan membentuk pola kombinasi datasets dengan menggunakan algoritma Fp-growth dalam data bencana tanahlongsor di Jawa Barat.

\subsection{Mencari Literature}

Pencarian literature atau referensi dilakukan untuk mencari berbagai sumber yang berkaitan tentang data mining, association rule mining, fp-growth dan tanah longsor. Adapun yang dilakukan oleh penulis adalah dengan melakukan studi pustaka. Dalam penelitian ini penulis menggunakan metode studi pustaka yang merupakan sebuah metode yang dilakukan dengan cara mengumpulkan dan mencari sumber dari buku, internet, jurnal yang berkaitan dengan penelitian yang dilakukan.

\subsection{Proses Pengumpulan Data}

Proses pengumpulan data dilakukan dengan cara mengambil data mentah yang berupa data dari website Badan Nasional Penanggulangan Bencana dan kantor Badan Penanggulangan Bencana Daerah Provinsi Jawa Barat. Dataset yang digunakan untuk proses data mining diambil dari http://geospasial.bnpb.go.id, tampilan dari bnpb.go.id dapat dilihat pada Gambar 2.

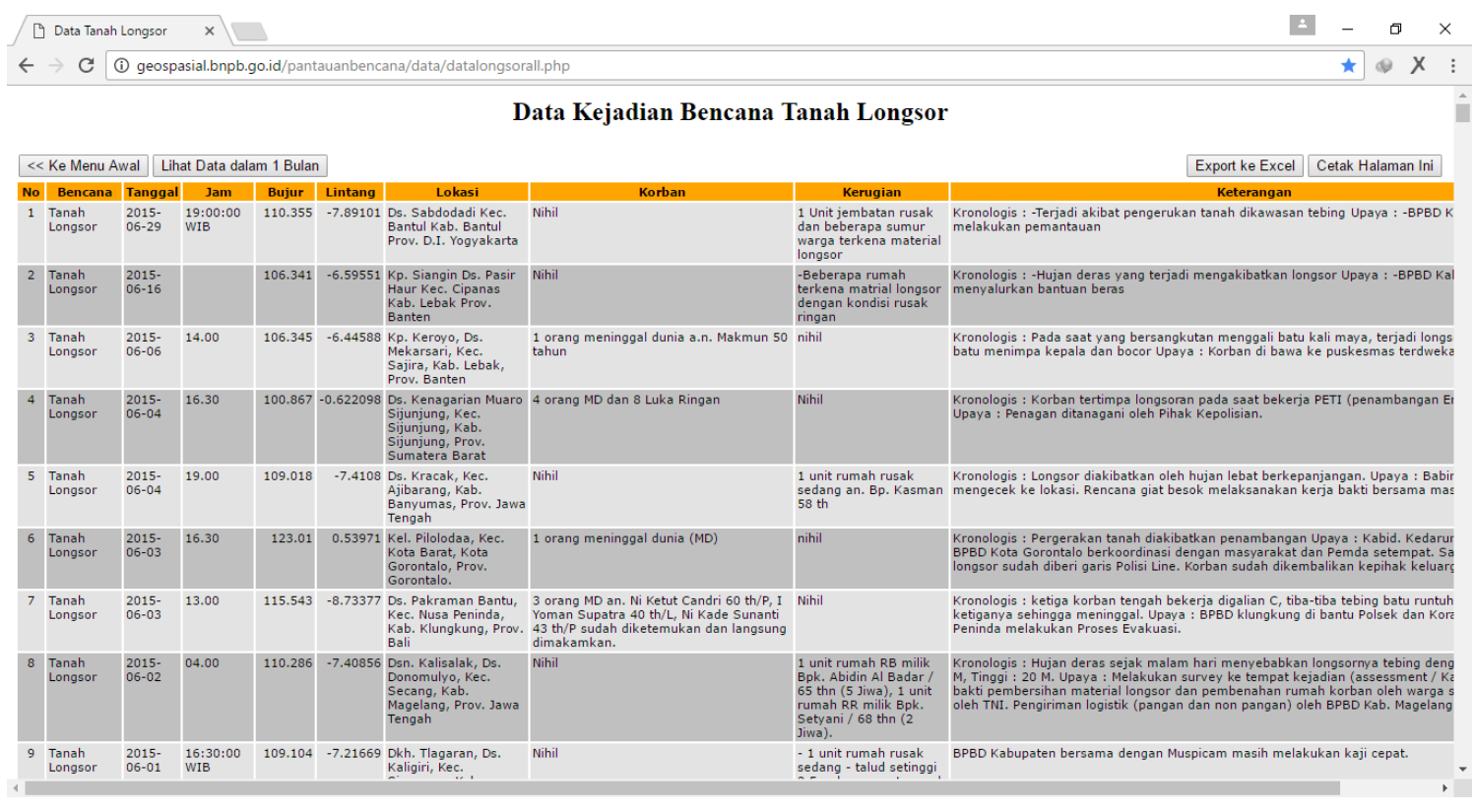

Gambar 2. Data Tanah Longsor dari BNPB

Data yang diambil adalah dari rentan tanggal 1 November 2011 sampai 5 Mei 2015 dengan jumlah 243 records. Tampilan data dari kantor Badan Penganggulangan Bencana Daerah Provinsi Jawa Barat seperti pada Gambar 3. 


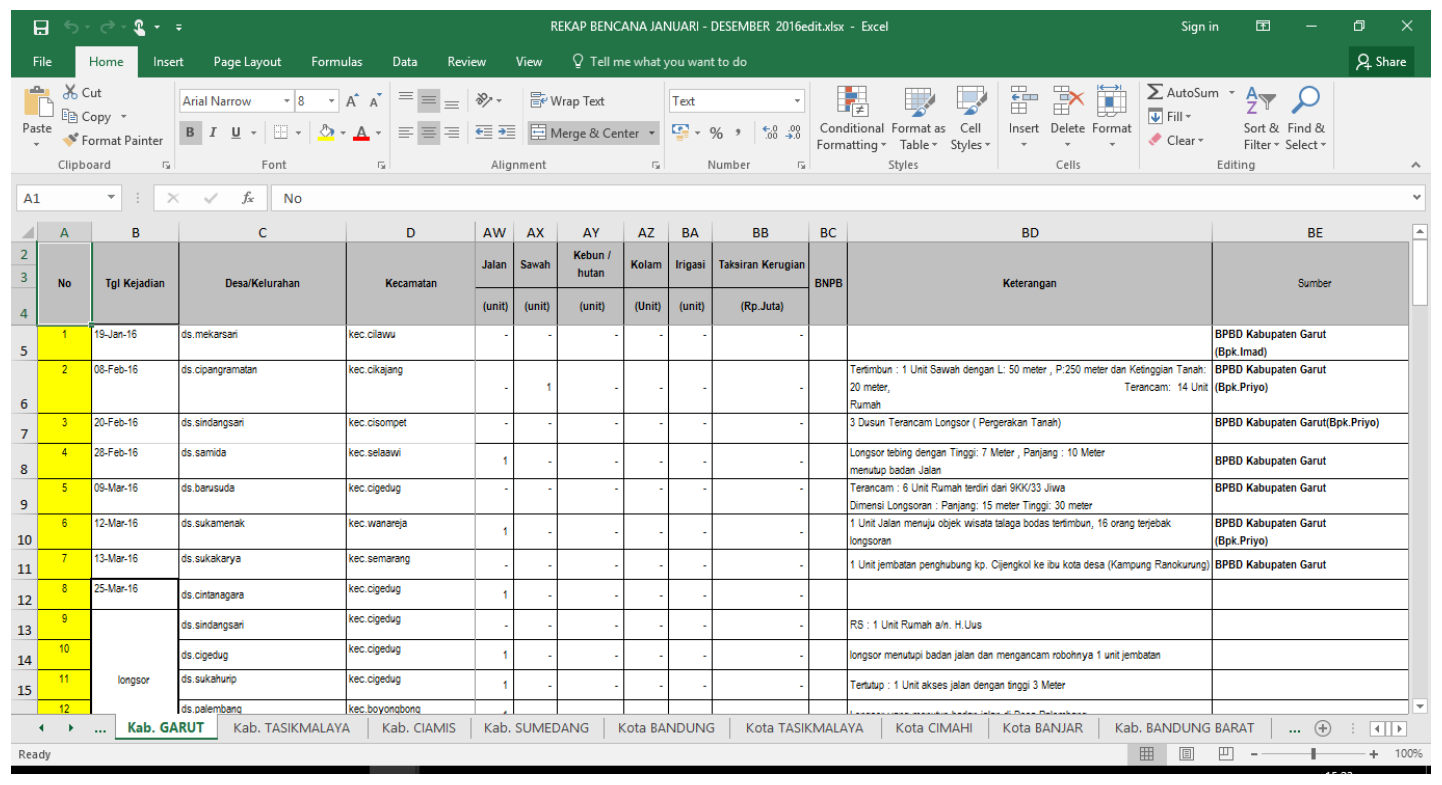

Gambar 3. Data Tanah Longsor dari BPBD Jawa Barat

Jumlah data yang diambil adalah dari rentan tanggal 1 Januari 2016 sampai 31 Desember 2016 dengan jumlah 164 records. Total seluruh data yang menjadi data primer berjumlah 407 records.

\subsection{Preparasi Data}

Proses reparasi adalah dilakukanya proses cleansing data, penentuan frequent item, dan repair data.

1. Proses Cleansing Data

Pembersihan data merupakan proses menghilangkan noise dan data yang tidak konsisten atau data tidak relevan [9].

2. Penentuan Frequent Item

Melakukan pencarian item yang paling sering muncul, apabila terdapat item yang tidak frequent atau kemunculan sedikit maka item akan dibuang. Dalam dataset ini item yang sering muncul adalah diantaranya penyebab_longsor, kerugian_longsor, nama_kecamatan, waktu_kejadian.

3. Repair Data

Data diubah atau digabung ke dalam format yang sesuai untuk diproses dalam data mining [9]. Transformasi atau repair data juga dapat menentukan kualitas dari hasil data mining nantinya karena ada beberapa karakteristik dari teknik-teknik data mining tertentu yang tergantung pada tahapan ini. Data yang telah melalui proses reparasi data menghasilkan dataset seperti Tabel 1dibawah ini.

Tabel 1. Data Setelah Dilakukan Proses Preparasi Data

\begin{tabular}{|c|c|c|c|c|c|}
\hline $\begin{array}{c}\text { Kejadian } \\
\text { Tanah } \\
\text { Longsor }\end{array}$ & Atribut & 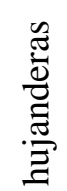 & 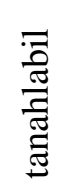 & 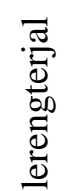 & 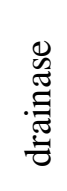 \\
\hline Longsor 1 & $\begin{array}{l}\text { hujanderas, tanahlabil, rumahrusak, korbanjiwa, } \\
\text { sukaraja, sore }\end{array}$ & 1 & 1 & 0 & 0 \\
\hline
\end{tabular}




\begin{tabular}{|c|c|c|c|c|c|}
\hline $\begin{array}{c}\text { Kejadian } \\
\text { Tanah } \\
\text { Longsor }\end{array}$ & Atribut & 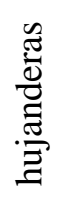 & 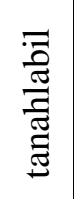 & 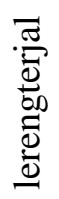 & 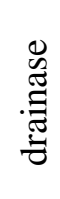 \\
\hline Longsor 2 & $\begin{array}{l}\text { penambanganliar, humanerror, rumahrusak, } \\
\text { jalanrusak, korbanjiwa, cisolok, sore }\end{array}$ & 0 & 0 & 0 & 0 \\
\hline Longsor 3 & $\begin{array}{l}\text { hujanderas, tanahlabil, rumahrusak, korbanjiwa, } \\
\text { cimanggis, sore }\end{array}$ & 1 & 1 & 0 & 0 \\
\hline Longsor 4 & hujanderas, tanahlabil, saluranrusak, garut, malam & 1 & 1 & 0 & 0 \\
\hline Longsor 5 & $\begin{array}{l}\text { hujanderas, tanahlabil, rumahrusak, sawahrusak, } \\
\text { parungpoteng, siang }\end{array}$ & 1 & 1 & 0 & 0 \\
\hline
\end{tabular}

\subsection{Proses dan Hasil}

Proses yang akan dilakukan penulis mencari asosiasi menggunakan algoritma Fp-growth yang akan menghasilkan nilai support, dan confidence

\subsection{Analisis}

Analisis dilakukan dengan cara mengamati dan menjelaskan hasil yang didapat dari proses pada rapidminer. Hasil berupa premises dan conclusion dari data serta support dan confidence dari premises dan conclusion tersebut.

\subsection{Penarikan Kesimpulan}

Kesimpulan akan dibuat sesuai dengan hasil penelitian yang dilakukan baik proses pada rapidminer dan analisis.

\section{HASIL DAN PEMBAHASAN}

\subsection{Pengujian Parameter Default}

Proses pengujian data ini dilakukan tanpa melakukan perubahan atau optimalisasi apapun pada algoritma yang digunakan ataupun berbagai plug-in yang terdapat pada rapidminer. Pengujian dilakukan menggunakan algoritma $F p$-growth dan teknik data mining Association Rule seperti digambarkan pada Gambar 4.

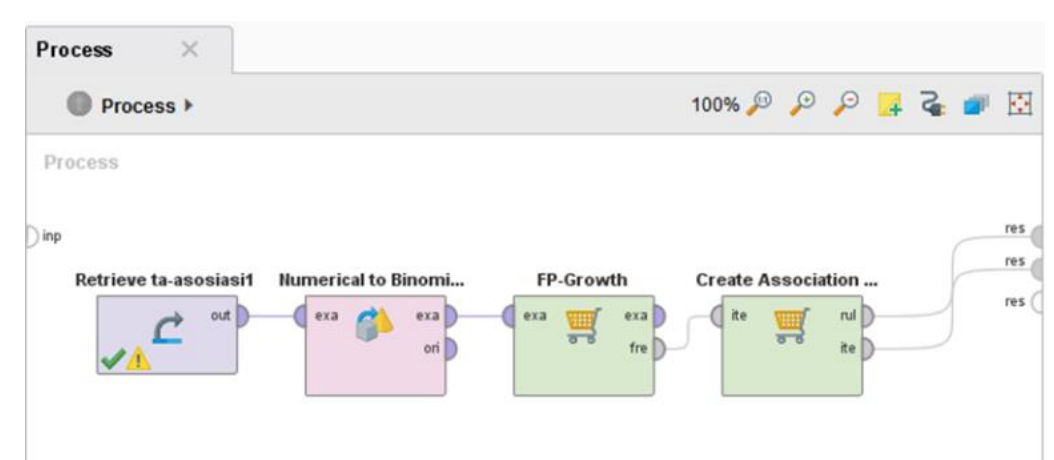

Gambar 4. Proses Data Mining Menggunakan Rapidminer

Dari hasil pengujian awal dengan menggunakan parameter default pada algoritma yang digunakan dan plug-in lainnya didapatkan hasil seperti pada Tabel 2 dibawah ini.

Tabel 2. Hasil Pengujian Parameter Default

\begin{tabular}{|c|l|c|c|c|}
\hline No & \multicolumn{1}{|c|}{ Premises } & Conclusion & Support & Confidence \\
\hline 1. & $\begin{array}{l}\text { tanahlabil, } \\
\text { korbanjiwa }\end{array}$ & hujanderas & 0,238 & 0,802 \\
\hline
\end{tabular}




\begin{tabular}{|c|l|c|c|c|}
\hline No & \multicolumn{1}{|c|}{ Premises } & Conclusion & Support & Confidence \\
\hline 2. & $\begin{array}{l}\text { tanahlabil, } \\
\text { korbanjiwa }\end{array}$ & rumahrusak & 0,238 & 0,802 \\
\hline 3. & tanahlabil & hujanderas & 0,511 & 0,819 \\
\hline 4. & korbanjiwa & hujanderas & 0,378 & 0,824 \\
\hline 5. & $\begin{array}{l}\text { rumahrusak, } \\
\text { tanahlabil }\end{array}$ & hujanderas & 0,383 & 0,857 \\
\hline 6. & $\begin{array}{l}\text { hujanderas, } \\
\text { korbanjwa }\end{array}$ & rumahrusak & 0,329 & 0,870 \\
\hline 7. & rumahrusak & hujanderas & 0,629 & 0,901 \\
\hline 8. & malam & hujanderas & 0,248 & 0,910 \\
\hline 9. & $\begin{array}{l}\text { rumahrusak, } \\
\text { korbanjiwa }\end{array}$ & hujanderas & 0,329 & 0,912 \\
\hline 10. & sore & hujanderas & 0,346 & 0,916 \\
\hline 11. & rumahrusak, sore & hujanderas & 0,246 & 0,917 \\
\hline 12. & jalanrusak & hujanderas & 0,243 & 0,934 \\
\hline
\end{tabular}

Dilihat dari hasil pengujian awal menggunakan parameter default, dari total keseluruhan dataset menghasilkan 12 hasil dengan nilai confidence paling tinggi yaitu 0,934 dengan premises jalan rusak dan conclusion hujan deras. Dengan kata lain kemungkinan sebesar 93\% terjadi tanah longsor jika kondisi jalan rusak maka hujan deras walaupun support 0,243 atau hanya terjadi dengan kemungkinan muncul sekitar $24 \%$ saja dari total data. Nilai confidence paling kecil dari pengujian awal dengan parameter default adalah sebesar 0,802 dengan premises tanah labil, korban jiwa dan conclusion rumah rusak. Dengan kata lain kemungkinan kejadian tanah longsor sebesar $80 \%$ jika kondisi tanah labil, korban jiwa maka rumah rusak dengan support hanya 0,238 atau kemungkinan muncul $23 \%$ saja dari total data.

\subsection{Pengujian Eksperimen}

Pengujian eksperimen adalah penelitian yang bertujuan untuk mengidentifikasi hubungan sebab akibat dari satu atau lebih variabel terikat dengan melakukan manipulasi variabel bebas pada suatu keadaan yang terkendali [10]. Dalam menentukan suatu association rule, terdapat suatu interestingness measure (ukuran ketertarikan) yang didapatkan dari hasil pengelolaan data dengan perhitungan tertentu. Terdapat dua ukuran yaitu support dan cofidence.

Kedua ukuran tersebut akan digunakan dalam menentukan interesting association rules, yaitu untuk dibandingkan dengan batasan (threshold) yang ditentukan oleh user. Batasan tersebut umumnya terdiri dari minimum support dan minimum confidence, yang digunakan pada proses pencarian association rules. Maka dari itu, penguji akan mencoba melakukan beberapa perubahan pada pengaturan parameter default dengan mengubah pengaturan min confidence dan min support menjadi seperti pada Gambar 5. 


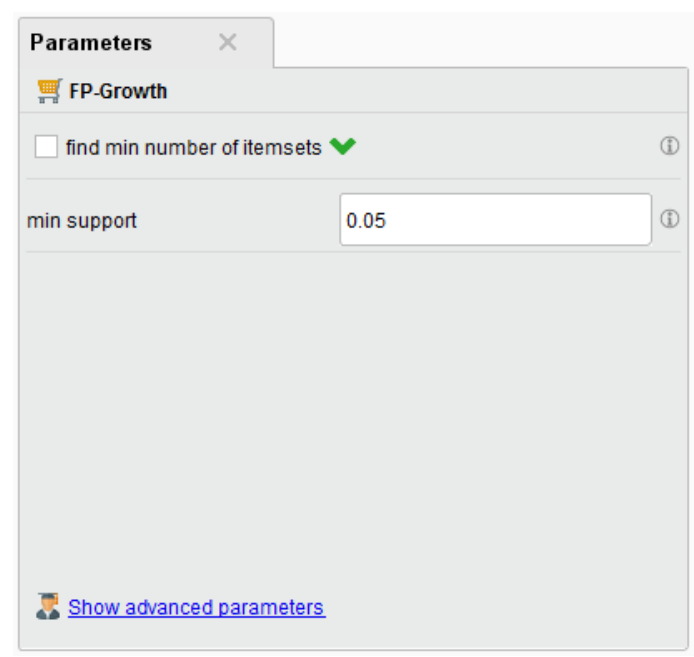

Gambar 5. Seting Parameter Support di Algoritma FP-Growth

Dalam gambar diatas penguji mengubah pengaturan find min number of itemsets menjadi tidak dipilih/diceklis supaya pengaturan min support terpakai. Untuk pengaturan min support penguji menetapkan 0.05 berdasarkan ada kemungkinan suatu kondisi memiliki peluang besar pasti berkaitan dengan kondisi yang lain meskipun konsidi tersebut jarang terjadi. Kondisi yang pasti tersebut dilihat dari besar kecilnya nilai confidence, maka dari itu penguji menetapkan nilai min confidence sebesar 0,9 seperti pada Gambar 6.

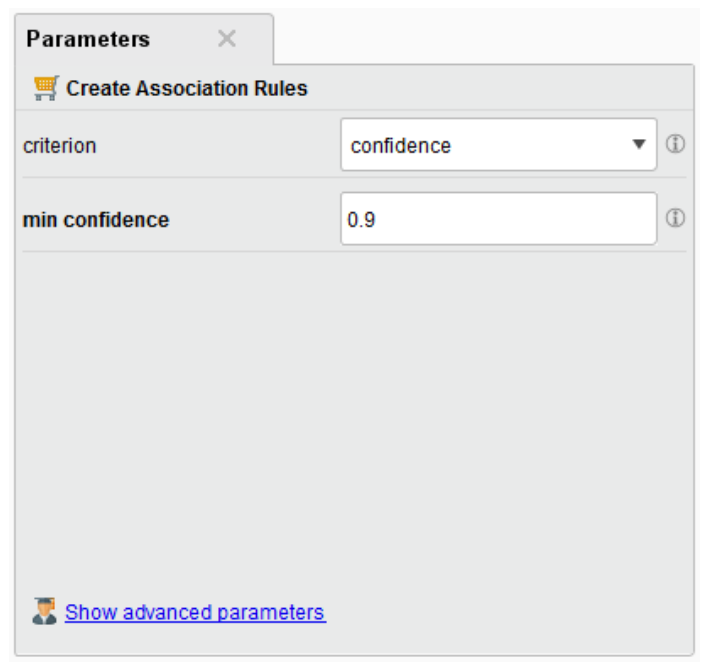

Gambar 6. Seting Parameter Confidence di Algoritma FP-Growth

Dari hasil pengujian eksperimen dengan mengubah parameter min support pada algoritma $\mathrm{Fp}$-growth menjadi 0.05 dan parameter min confidence pada association rules menjadi 0.9 didapatkan hasil seperti pada Table 3 .

Tabel 3. Hasil Pengujian Setelah Dilakukan Perubahan Parameter

\begin{tabular}{|c|l|l|c|c|}
\hline No & Premises & Conclusions & Support & Confidence \\
\hline 1 & tanahlabil, korbanjiwa, sore & hujanderas & 0,066 & 0,900 \\
\hline 2 & tanahlabil, korbanjiwa, sore & rumahrusak & 0,066 & 0,900 \\
\hline 3 & rumahrusak & hujanderas & 0,629 & 0,901 \\
\hline
\end{tabular}




\begin{tabular}{|c|c|c|c|c|}
\hline No & Premises & Conclusions & Support & Confidence \\
\hline 4 & rumahrusak, jalanrusak & hujanderas & 0,091 & 0,902 \\
\hline 5 & rumahrusak, tanahlabil, malam & hujanderas & 0,140 & 0,905 \\
\hline 6 & tanahlabil, jalanrusak & hujanderas & 0,143 & 0,906 \\
\hline 7 & Malam & hujanderas & 0,248 & 0,910 \\
\hline 8 & rumahrusak, korbanjiwa & hujanderas & 0,329 & 0,912 \\
\hline 9 & hujanderas, korbanjiwa, sore & rumahrusak & 0,103 & 0,913 \\
\hline 10 & Sore & hujanderas & 0,346 & 0,916 \\
\hline 11 & rumahrusak, drainase & hujanderas & 0,054 & 0,917 \\
\hline 12 & korbanjiwa, jalanrusak & hujanderas & 0,054 & 0,917 \\
\hline 13 & rumahrusak, sore & hujanderas & 0,246 & 0,917 \\
\hline 14 & sore, jalanrusak & hujanderas & 0,111 & 0,918 \\
\hline 15 & sore, jalanrusak & hujanderas & 0,194 & 0,929 \\
\hline 16 & rumahrusak, korbanjiwa, sore & hujanderas & 0,103 & 0,933 \\
\hline 17 & jalanrusak & hujanderas & 0,243 & 0,934 \\
\hline 18 & $\begin{array}{l}\text { rumahrusak, tanahlabil, } \\
\text { korbanjiwa, malam }\end{array}$ & hujanderas & 0,081 & 0,943 \\
\hline 19 & drainase & hujanderas & 0,086 & 0,946 \\
\hline 20 & rumahrusak, korbanjiwa, malam & hujanderas & 0,111 & 0,957 \\
\hline 21 & $\begin{array}{l}\text { hujanderas, tanahlabil, } \\
\text { korbanjiwa, sore }\end{array}$ & rumahrusak & 0,064 & 0,963 \\
\hline 22 & $\begin{array}{l}\text { rumahrusak, tanahlabil, } \\
\text { korbanjiwa, sore }\end{array}$ & hujanderas & 0,064 & 0,963 \\
\hline 23 & $\begin{array}{l}\text { hujanderas, tanahlabil, } \\
\text { korbanjiwa, malam }\end{array}$ & rumahrusak & 0,081 & 0,971 \\
\hline 24 & malam, jalanrusak & hujanderas & 0,088 & 1 \\
\hline 25 & tanahlabil, malam, jalanrusak & hujanderas & 0,074 & 1 \\
\hline
\end{tabular}

Dilihat dari hasil pengujian eksperimen dengan mengubah parameter min support pada algoritma $F$ p-growth menjadi 0.05 dan parameter min confidence pada association rules menjadi 0.9 didapatkan 25 hasil dengan nilai confidence paling tinggi yaitu 1. Dengan confidence dengan nilai 1 bisa dipastikan bahwa premises dan conclusion-nya terkait. Dalam 25 hasil terdapat 2 hasil yang mendapatkan conclusion sebesar 1. Yang pertama dengan premises malam, jalan rusak dan conclusion hujan deras. Dengan kata lain kemungkinan kejadian tanah longsor sebesar $100 \%$ jika kondisi malam, jalan rusak maka hujan deras dengan support hanya 0,088 atau kemungkinan muncul $8,8 \%$ saja dari total data yang berarti jarang sekali terjadi namun pasti berkaitan. Yang kedua dengan premises tanah labil, korban jiwa, sore dan conclusion hujan deras. Yang juga kemungkinan kejadian tanah longsor sebesar $100 \%$ jika kondisi tanah labil, korban jiwa, malam maka hujan deras dengan support hanya 0,074 atau kemungkinan muncul 7,4\% saja dari total data yang berarti juga jarang sekali terjadi namun pasti berkaitan.

Dalam hasil pengujian eksperimen hasil nilai support tertinggi yaitu sebesar 0,629 dengan confidence 0,901 dengan premises rumah rusak dan conclusion hujan deras. Yang berarti, kemungkinan terjadi tanah longsor sebesar $90 \%$ jika kondisi rumah rusak maka hujan deras dengan nilai support $63 \%$ atau bisa dikatakan hampir sering terjadi. Dari ke-25 hasil pengujian eksperimen dapat dikatakan sebagai valid association rule karena memenuhi nilai min confidence yang telah ditentukan. Tabel 4.

Dari pengujian eksperimen didapatkan 10 item dengan nilai support tertinggi seperti pada 
Tabel 4. Nilai Support Tertinggi

\begin{tabular}{|l|c|}
\hline \multicolumn{1}{|c|}{ Item } & Support \\
\hline hujanderas & 0,865 \\
\hline rumahrusak & 0,689 \\
\hline tanahlabil & 0,624 \\
\hline korbanjiwa & 0,459 \\
\hline sore & 0,378 \\
\hline malam & 0,273 \\
\hline jalanrusak & 0,26 \\
\hline pagi & 0,243 \\
\hline siang & 0,108 \\
\hline lerengterjal & 0,106 \\
\hline
\end{tabular}

Dari tabel 4 dapat disimpulkan bahwa hujan deras dan tanah labil sebagai penyebab tanah longsor paling tinggi dengan nilai support 0,865 untuk hujan deras dan 0,624 untuk tanah labil. Kerusakan terbesar akibat tanah longsor adalah rumah rusak dengan support 0,689. Dan waktu kejadian paling banyak terjadi pada sore hari dengan support 0,378 .

Hasil yang dicapai adalah sebuah pengetahuan yang dapat membantu pemerintah daerah Provinsi Jawa Barat dalam pengambilan keputusan, sehingga dengan pengetahuan ini pemerintah bisa lebih siaga, bahwa akibat hujan deras dan tanah labil yang faktor utama yang menyebabkan terjadinya longsor di daerah Jawa Barat, sehinga mengakibatkan kerugian akibat tanah longsor yaitu rusaknya rumah - rumah penduduk yang bencana longsor ini sering terjadi pada sore hari.

\subsection{Perbandingan Hasil}

Perbandingan hasil support antara pengujian parameter default dengan pengujian eksperimen digambarkan pada Gambar 7 dibawah ini :

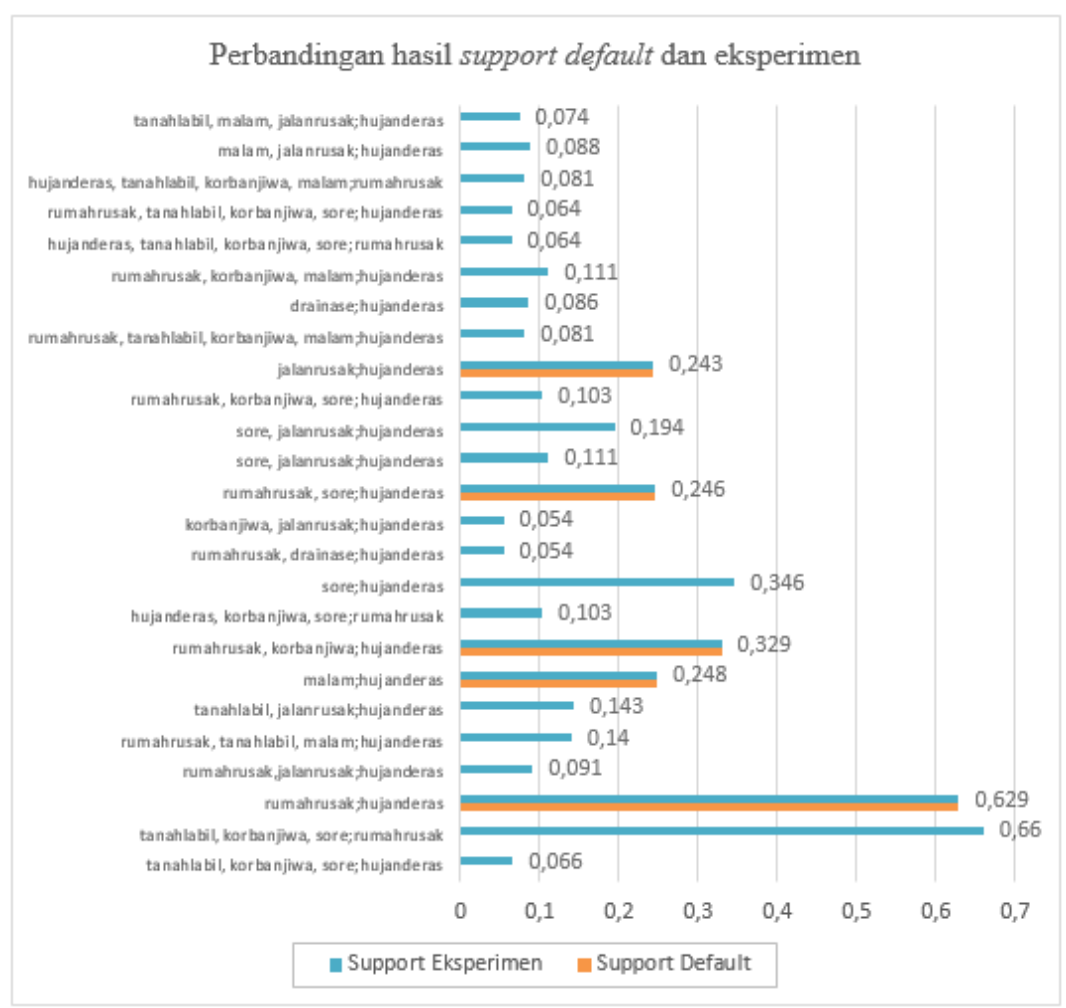

Gambar 7. Perbandingan Nilai Support Hasil Pengujian Parameter Default dan Eksperimen 
Sedangkan Perbandingan hasil confidence antara pengujian parameter default dengan pengujian eksperimen digambarkan pada Gambar 8.

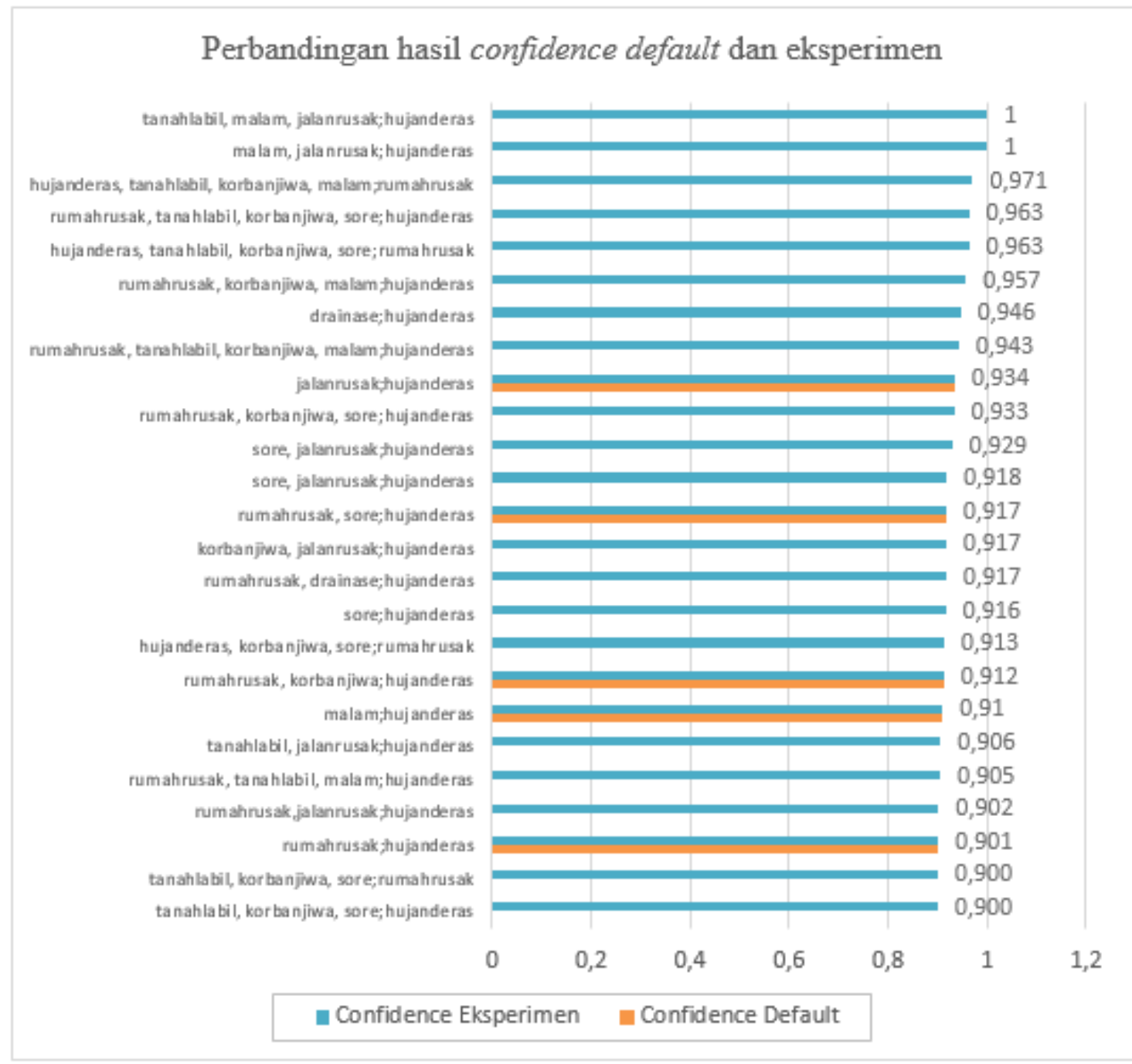

Gambar 8. Perbandingan Nilai Confidence Hasil Pengujian Parameter Default dan Eksperimen

Dari grafik menunjukan 25 hasil dari pengujian parameter default dan pengujian eksperimen. Dari 25 hasil hanya 5 yang digambarkan mempunyai 4 bar dalam grafik yang berarti 5 hasil tersebut muncul dikedua hasil pengujian dengan nilai support dan confidence yang sama dan terdapat 20 hasil lainnya yang hanya muncul dalam pengujian eksperimen saja.

\section{KESIMPULAN}

Berdasarkan hasil penelitian yang dilakukan oleh penulis maka penulis menarik kesimpulan sebagai berikut:

1. Dari pembahasan di atas dapat diketahui bahwa penggunaan metode association rule mining dengan algoritma fp-growth dapat diimplementasikan dalam data kebencanaan.

2. Pola hubungan asosiatif yang terjadi dari data tanah longsor di Jawa Barat dari periode 2011 sampai 2016 mendapatkan hasil confidence tertinggi sebesar 1 yang didapatkan dari hasil pengujian eksperimen. Pengujian eksperimen memungkinkan menghasilkan suatu kondisi memiliki peluang besar pasti berkaitan karena pengaturannya disesuaikan dengan kebutuhan. Dari semua hasil yang mendapatkan: 
a. Didapatkan 2 hasil confidence sebesar 1 :

1) Dengan premises malam, jalan rusak dan conclusion hujan deras dengan support 0,088 . Yang berarti jarang sekali terjadi namun $100 \%$ pasti berkaitan.

2) Dengan premises tanah labil, korban jiwa, sore dan conclusion hujan deras dengan support 0,074 . Yang juga berarti jarang sekali terjadi namun $100 \%$ pasti berkaitan.

b. Dalam pengujian eksperimen juga mengasilkan pola asosiatif dengan nilai support tertinggi sebesar 0,629 dengan confidence 0,901 dengan premises rumah rusak dan conclusion hujan deras. Yang berarti sering terjadi dan $90 \%$ kemungkinan berkaitan.

\section{SARAN}

Beberapa saran untuk penelitian selanjutnya adalah sebagai berikut:

1. Untuk mendapatkan hasil yang lebih real disarankan untuk selalu memperbaharui data bencana longsor yang terjadi di Jawa Barat dan juga menambahkan indikator-indikator lain seperti kelembapan, curah hujan, dan lain-lain yang mempunyai impact atau berkaitan dengan bencana tanah longsor.

2. Untuk penelitian selanjutnya, melakukan percobaan menggunakan algoritma lain sebagai pembanding.

\section{DAFTAR PUSTAKA}

[1] www.jabarprov.go.id, "Koramil Giriwangin Bantu Bersihkan Longsoran," 2016. [Online]. Available: http://www.jabarprov.go.id/index.php/news/20215/2016/11/29/KoramilGiriwangin-Bantu-Bersihkan-Longsoran. [Accessed: 25-Jul-2017].

[2] Pusat Vulkanologi Mitigasi Bencana Geologi, "Dikepung Bencana Alam,” 2016. .

[3] A. Siswandi, "Tanah Longsor dan Banjir Paling Sering Terjadi di Jawa Barat," www.tempo.com, $2016 . \quad$ [Online]. Available: http://www.tempo.co/read/news/2016/11/10/058819325/tanah-longsor-dan-banjirpaling-sering-terjadi-di-jawa-barat. [Accessed: 24-Jul-2017].

[4] D. Setianingsih and R. F. Hakim, "Penerapan Data Mining dalam Analisis Kejadian Tanah longsor di Indonesia dengan Menggunakan Association Rule Algoritma Apriori," Univ. Islam Indones., pp. 731-741, 2015.

[5] M. I. Ramadhan and Prihandoko, "PENERAPAN DATA MINING UNTUK ANALISIS DATA BENCANA MILIK BNPB MENGGUNAKAN ALGORITMA K-MEANS DAN LINEAR REGRESION," Inform. dan Komput., vol. 22, no. 1, pp. 57-65, 2017.

[6] M. F. Afif, "Penerapan Algoritma Self Organizing Map dalam Memetakan Dareah Rawan Bencana Alam Tanah Longsor di Indonesia," Universitas Negeri Yogyakarta, 2017.

[7] J. Han and J. Pei, "Mining Frequent Patterns by Pattern-Growth: Methodology and Implications," SIGKDD Explor., vol. 2, no. 2, p. 14, 2000.

[8] W. A. Triyanto, V. Suhartono, and H. Himawan, "Analisis Keranjang Pasar Menggunakan algoritma KMedoids dan FP-Growth,” J. Pseudocode, vol. 2, no. 1, pp. 129-142, 2014.

[9] J. Han and M. Kamber, Data Mining: Concepts and Techniques 2nd Edition, Second Edi. San Francisco: Elsevier, 2006.

[10] F. Rofiah, "Metode Penelitian Eksperimen," Eureka Pendidikan, 2015. [Online]. Available: $\quad$ http://www.eurekapendidikan.com/2015/11/metode-penelitianeksperimen.html. [Accessed: 14-Jul-2017]. 